\title{
The Effect of Service Quality and Tax Sanctions on Service Satisfaction
}

\author{
Hendra Hadiwijaya ${ }^{1 *}$, Febrianty ${ }^{2}$ \\ *Corresponding author
}

\begin{abstract}
This study aimed to analyze the effect of service quality and tax sanctions on service satisfaction and its implementation on compliance to pay personal vehicle tax. This study uses Structural Equation Modeling (SEM) as tools of analysis. The result shows that service quality affects service satisfaction, and it implies compliance with the personal vehicle tax payable compliance. Besides that, the tax sanctions affect service satisfaction, and it implies compliance with paying personal vehicle tax. Tax sanctions are a prevention tool for violations committed by taxpayers, If Service Satisfaction fails to meet expectations, and taxpayers will feel dissatisfied. If Service Satisfaction is in line with expectations, taxpayers will feel satisfied. If Service Satisfaction exceeds expectations, taxpayers will be very satisfied.
\end{abstract}

Keywords: service quality, tax sanctions, service satisfaction, tax payable compliance

JEL classification: K34, M31

\begin{abstract}
Abstrak. Penelitian ini bertujuan untuk menganalisis pengaruh kualitas layanan dan sanksi pajak terhadap kepuasan layanan dan implementasinya terhadap kepatuhan membayar pajak kendaraan pribadi. Penelitian ini menggunakan alat analisis model persamaan struktural (SEM). Kualitas layanan memiliki pengaruh pada kepuasan layanan dan implikasinya untuk kepatuhan terhadap kepatuhan pajak kendaraan pribadi. Sanksi pajak memiliki pengaruh pada kepuasan layanan dan implikasinya untuk kepatuhan membayar pajak kendaraan pribadi. Sanksi pajak adalah alat pencegahan untuk pelanggaran yang dilakukan oleh wajib pajak, Jika Kepuasan layanan gagal memenuhi harapan, dan wajib pajak akan merasa tidak puas. Apabila kepuasan layanan sesuai dengan harapan, wajib pajak akan merasa puas. Namun, apabila kepuasan layanan melebihi harapan, wajib pajak akan sangat puas.
\end{abstract}

Kata Kunci: kualitas layanan, sanksi pajak, kepuasan layanan, kepatuhan membayar pajak

\section{How to Cite:}

Hadiwijaya, H., \& Febrianty. (2019). The Effect of Service Quality and Tax Sanctions on Service Satisfaction. Etikonomi: Jurnal Ekonomi. Vol. 18 (2): 197 - 208. doi: http//dx.doi.org/10.15408/etk.v18i2.7428. 


\section{Introduction}

Service quality is one of the vital strategies for institutions, even in public sector organizations. Customer needs and expectations are changing when it comes to governmental services (Ramseook-Munhurrun et al., 2010). Policymakers need to make quality reforms for public enterprises. This research will examine the service quality in the public sector at UPTD Palembang Local Revenue Office of South Sumatra Province. We are going to examine does the service quality will affect the tax revenue. The good Service quality will affect the taxpayer; thus, the taxpayer in fulfilling obligations in paying taxes then avoids tax sanctions, and also, the income received by UPTD Palembang increased.

Taxation sanction is applied as a result of the non-fulfillment of tax obligations by the taxpayer as mandated in the Taxation Law. The imposition of tax sanction to the Taxpayer may cause the fulfillment of tax obligations by the Taxpayer so that it can improve the Taxpayer's compliance. Taxpayers will be obedient (because of the pressure) because they think there are severe sanctions due to illegal actions in an attempt the smuggle taxes (Devano \& Rahayu, 2016). Tax sanction is an act given to taxpayers or officials associated with taxes that committed violations either intentionally or because of negligence. Tax sanction is a guarantee that the provisions of tax laws and regulations. In other words, taxation sanction is a deterrent that means that taxpayers do not violate the norms of taxation (Mardiasmo, 2009). In the Taxation Act known two kinds of sanctions, namely administrative sanctions and criminal sanctions.

According to Suwardi \& Utomo (2011), satisfaction has a vital role in order to support the achievement of agency goals, because Satisfaction contributes significantly to the effectiveness of the organization, as well as stimulating the spirit of work and loyalty. Customer satisfaction influenced by expectations and perceived service quality (Andreassen, 1994). Andreassen (1995) states that public services offer to the public based on the principle of equality, so it is also essential to know how much level of satisfaction with the public service it receives.

According to Devano \& Rahayu (2016), compliance in taxation is compliance, submission, and compliance and implements the provisions taxation. Compliance that does not show improvement will threat government efforts in improving people's welfare (Chau $\&$ Leung, 2009). Obedient taxpayers were taxpayers who are obedient in fulfilling and carrying out taxation obligations following the provisions of tax laws. Tax compliance is the act of the taxpayer in the fulfillment of tax obligations. Obedient taxpayers are compliant and obedient and have no arrears or delays in tax deposits.

Susmita \& Upadmi conducted the research (2016), obtained that the service quality, taxation sanction, and application of e-filing have a positive effect on WP OP compliance. While tax compliance cost has a negative effect on personal taxpayers' compliance, other research conducted by Putri \& Setiawan (2017) shows that the awareness of taxpayers, knowledge, and understanding of tax laws, service quality, and tax sanctions have a positive effect on taxpayer compliance. Septarini (2015) states that tax sanctions have a positive effect on taxpayer compliance. It is different from research by Asbar et al., (2014), and Hardiningsih \& Yulianawati (2011) states that tax sanctions do not affect taxpayer compliance. The more stringent tax penalties imposed on taxpayers, it can increase 
taxpayer compliance. If tax sanctions not strictly dealt with, compulsory tax compliance will decrease.

This study aimed to analyze the magnitude of the effect of service quality and tax sanctions on service satisfaction and its implementation on compliance to pay personal vehicle tax at UPTD Palembang Local Revenue Office of South Sumatra Province. This research contributes to deepening the study of service satisfaction.

\section{Methods}

The number of Populations in this research amount to 550,732. The selection of respondents used the Proportional Random Sampling method. Determination of sample size from a population used Slovin formula. Based on the calculation using Slovin's formula, the sample size is 400 respondents.

The methods used to collect data in this research are: First, observation; Second, questionnaire. The analysis of this research used Structural Equation Modeling (SEM) Analysis. The path diagram that show the causality relationship is showing in Figure 1.

Figure 1 Model SEM

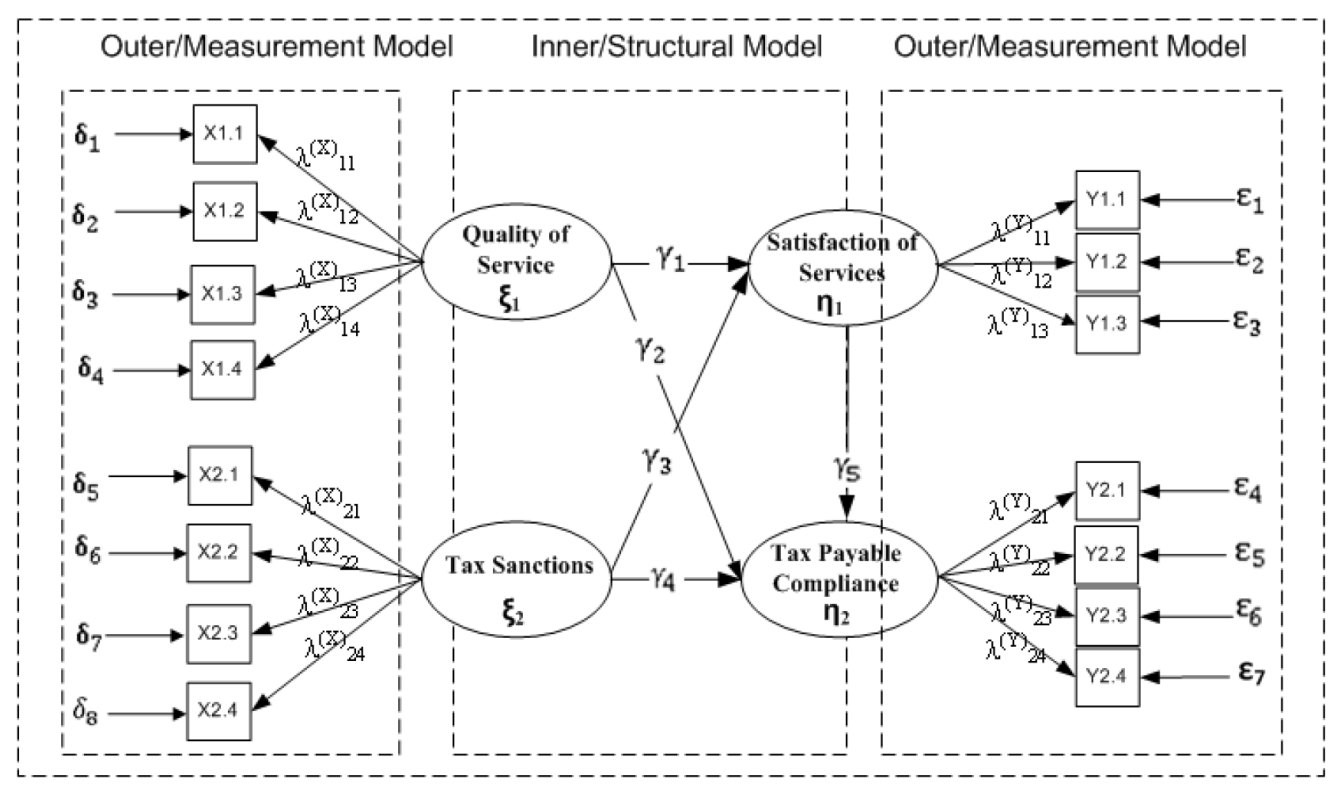

Structural model / inner model equation:

$\eta=\beta_{\Phi}+\beta_{\eta}+\Gamma \xi+\zeta$

\section{Description:}

$\eta$ is an endogenous construct vector.

$\xi$ is an exogenous construct vector.

$\Gamma$ is the path coefficient matrix.

$\zeta$ is a vector of residual variables (unexplained variance).

$\beta$ is the endogenous variable path coefficient $(\eta)$ and exogenous variables $(\xi)$. 


\section{Result and Discussion}

The first thing to do in this study is testing the validity of the research instruments. This test aimed to examine whether each item of the instrument (statement) was able to reveal the factors that had a measure. The validity value of each statement shows the Corrected itemtotal Correlation value of each statement. If the Corrected item-total Correlation value $>0.3$, then the measuring device or statement item is valid. The validity result is showing in Table 1.

Table 1. Validity Item Testing of Questionnaire Statement

\begin{tabular}{|c|c|c|c|c|c|}
\hline & & $\begin{array}{l}\text { Scale Mean if Item } \\
\text { Deleted }\end{array}$ & $\begin{array}{l}\text { Scale Variance if } \\
\text { Item Deleted }\end{array}$ & $\begin{array}{l}\text { Corrected Item- } \\
\text { Total Correlation }\end{array}$ & $\begin{array}{c}\text { Cronbach's Alpha if Item } \\
\text { Deleted }\end{array}$ \\
\hline \multirow{4}{*}{ QS } & $\mathrm{X} 11$ & 73.50 & 35.983 & .633 & .910 \\
\hline & $\mathrm{X} 12$ & 73.47 & 35.499 & .712 & .908 \\
\hline & $\mathrm{X} 13$ & 73.53 & 35.292 & .666 & .909 \\
\hline & X14 & 73.70 & 37.183 & .369 & .917 \\
\hline \multirow{4}{*}{ TS } & $X 21$ & 73.63 & 35.964 & .695 & .909 \\
\hline & $X 22$ & 73.67 & 35.402 & .708 & .908 \\
\hline & $X 23$ & 73.90 & 36.852 & .430 & .915 \\
\hline & $X 24$ & 73.63 & 36.723 & .553 & .912 \\
\hline \multirow{3}{*}{ SS } & Y11 & 73.77 & 34.185 & .721 & .907 \\
\hline & Y12 & 73.67 & 35.885 & .626 & .910 \\
\hline & Y13 & 73.70 & 35.803 & .579 & .911 \\
\hline \multirow{4}{*}{ TPC } & Y21 & 72.57 & 35.220 & .687 & .909 \\
\hline & Y22 & 72.50 & 35.224 & .767 & .907 \\
\hline & Y23 & 72.57 & 34.737 & .766 & .906 \\
\hline & Y24 & 72.67 & 35.402 & .708 & .908 \\
\hline
\end{tabular}

Source: Data processing

Table 1 shows that the validity test of 30 taxpayers of personal vehicles with Corrected item-total Correlation value> 0.3 on all items in the variable of Service Quality Impact (QS) and Tax Sanction (TS) on Service Satisfaction SS) and its implementation on Personal Vehicle Tax Pay Compliance (TPC) at UPTD Palembang Regional Revenue Service of South Sumatera Province, so that the data can be analyzed further.

Table 2. Reliability Testing of Questionnaire Statement Item

\begin{tabular}{lcccc}
\hline & $\begin{array}{c}\text { Scale Mean if } \\
\text { Item Deleted }\end{array}$ & $\begin{array}{c}\text { Scale Variance if } \\
\text { Item Deleted }\end{array}$ & $\begin{array}{c}\text { Corrected Item- } \\
\text { Total Correlation }\end{array}$ & $\begin{array}{c}\text { Cronbach's Alpha if } \\
\text { Item Deleted }\end{array}$ \\
\hline Service Quality (QS) & 8.5878 & 2.640 & .745 & .919 \\
Tax Sanctions (TS) & 8.4516 & 2.427 & .756 & .929 \\
Service Satisfaction (SS) & 8.5776 & 2.630 & .765 & .939 \\
Personal Vehicle Tax Payable & 8.3505 & 2.476 & .820 & .928 \\
Compliance (TPC) & & & & \\
\hline
\end{tabular}

Source: Data processing 
Furthermore, the research instrument will test for reliability. The reliability test is using Cronbach's Alpha method. The reliability of a variable construct is said to be good if it has a Cronbach's Alpha value> 0.60. Table 2 shows that the reliability test with Cronbach's Alpha value> 0.60 all the items (items) in all variables were reliable.

Figure 2. Model_1 CFA Exogenous Construct

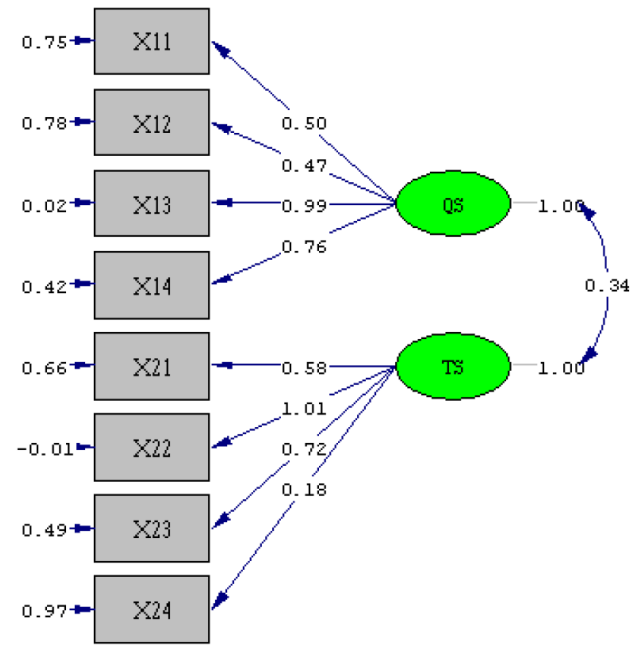

Measurement Model to test the validity and reliability of latent construction construct indicators did by confirmatory factor analysis (CFA). Exogenous CFA Model Constructs shows in Figure 2. Figure 2 shows that in Model_1 CFA Exogenous Construct, there is a loading factor load value less than 0.5 . This result means that indicators are not yet valid and must exclude in subsequent analysis.

Figure 3. Model_2 CFA Exogenous Construct

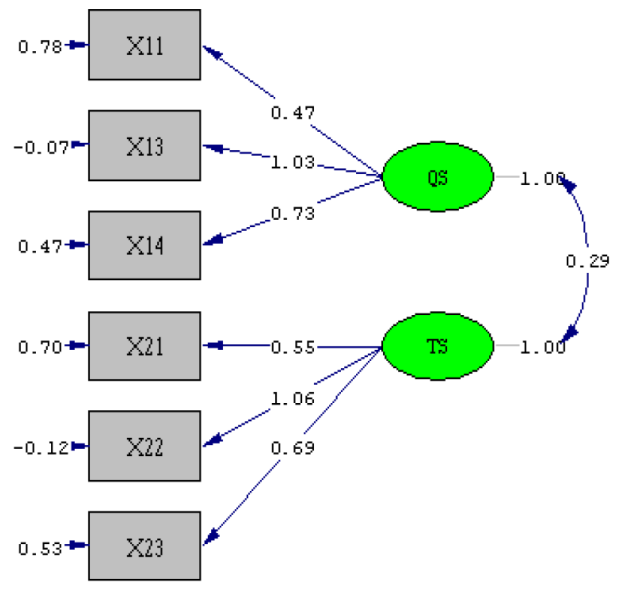

Thus, the Model_2 CFA endogenous construct obtains in Figure 3. Based on figure 3., it can show that on Model_2 CFA Exogenous Construct, there is a loading factor value less than 0.5 . This result means that the indicators are not valid yet and must issue in subsequent analysis. 
Figure 4. Model_3 CFA Exogenous Construct

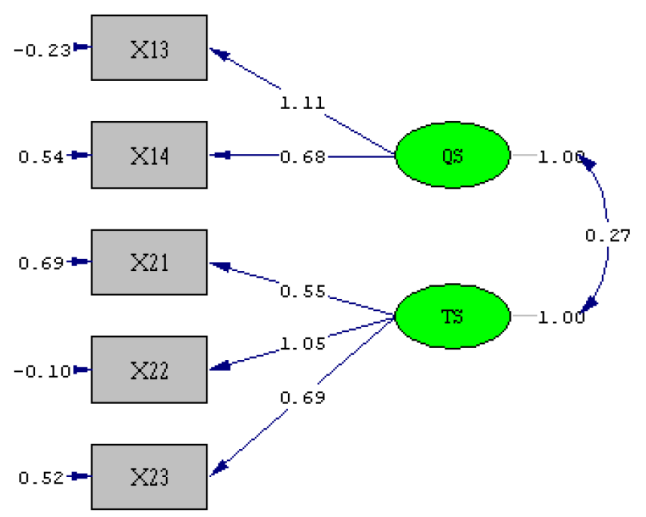

Thus obtained the Model_3 CFA Endogenous Construct. Based on figure 4, it indicates that in Model_3 CFA exogenous construct of Quality of Service (QS) and Tax Sanctions (TS) have no loading factor load value less than 0.5 , so all the indicators on the exogenous variables are already valid.

Table 3. Validity Indicator and Reliability Test of Exogenous Variable Constructs

\begin{tabular}{ccccc}
\hline Dimension & Indicator & $\lambda$ & Error $=1-\lambda^{2}$ & $\mathrm{CR}=(\Sigma \lambda)^{2} /\left((\Sigma \lambda)^{2}+\Sigma\right.$ Error $)$ \\
\hline \multirow{2}{*}{ Quality Of Service (QS) } & $\mathrm{X} 13$ & 1.11 & -0.23 & 0.912 \\
& $\mathrm{X} 14$ & 0.68 & 0.54 & \\
\multirow{2}{*}{ Tax Sanctions (TS) } & $\mathrm{X} 21$ & 0.55 & 0.69 & 0.825 \\
& $\mathrm{X} 22$ & 1.05 & -0.10 & \\
& $\mathrm{X} 23$ & 0.69 & 0.52 & \\
\hline
\end{tabular}

The results of reliability calculations on Quality of Service (QS) and Tax Sanctions (TS) variables are showing in Table 3. Table 3 shows that the Construct Reliability (CR) value of all exogenous constructs is above 0.7 . Thus, it can conclude that all dimensions of service quality and tax sanctions have excellent reliability and validity.

Figure 5. Model_1 CFA Endogenous Construct

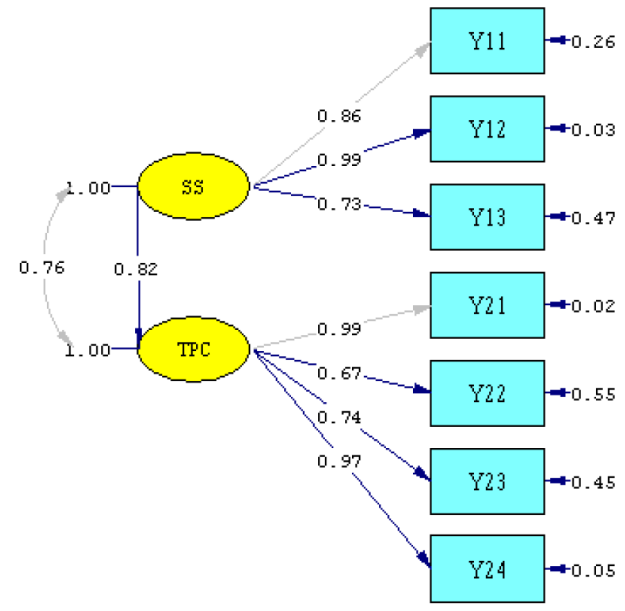


Confirmatory Factor Analysis of Endogenous Construct shows in Figure 5. Based on Figure 5 indicates that in the Model_1 CFA Endogenous Constructs, there is no loading factor value less than 0.5 , so all the indicators on the Satisfaction of Services (SS) and Personal Vehicle Tax Payable Compliance (TPC) variables have been valid.

Table 4. Validity Indicator and Reliability Test of Endogenous Variable Constructs

\begin{tabular}{ccccc}
\hline Dimensi & Indicator & $\lambda$ & Error $=1-\lambda^{2}$ & $\mathrm{CR}=(\Sigma \lambda)^{2} /\left((\Sigma \lambda)^{2}+\Sigma\right.$ Error $)$ \\
\hline \multirow{2}{*}{$\begin{array}{c}\text { Satisfaction of Services } \\
\text { (SS) }\end{array}$} & $\mathrm{Y} 11$ & 0.86 & 0.26 & \\
& $\mathrm{Y} 12$ & 0.99 & 0.03 & 0.898 \\
\hline & $\mathrm{Y} 13$ & 0.73 & 0.47 & \\
Personal Vehicle Tax & $\mathrm{Y} 22$ & 0.99 & 0.02 & 0.914 \\
Payable Compliance & Y23 & 0.67 & 0.55 & \\
(TPC) & Y24 & 0.74 & 0.45 & \\
& & & 0.05 & \\
\hline
\end{tabular}

The results of reliability calculations with Construct Reliability of Confirmatory Factor Analysis/CFA endogenous variables can show in Table 4. Based on Figures 5 and Table 4 indicates that the Model_1CFA endogenous construct has no loading factor load value less than 0.5 , which indicates that all indicators in the endogenous variable are valid. While the value of Construct Reliability (CR) shows that of all exogenous constructs is above 0.7 . Thus, it can conclude that all dimensions and variables of research in the Full Model have excellent reliability.

Table 5. The Goodness of Fit Index

\begin{tabular}{|c|c|c|c|c|}
\hline No & The Goodness of Fit Index & Value & Cut off Value & Information \\
\hline \multirow[b]{2}{*}{1.} & Chi-Square & 406.23 & $<$ a.df & \multirow[b]{2}{*}{ Good Fit } \\
\hline & Probability & 0.051 & $\begin{array}{c}>0.05 \\
0.01-0.05\end{array}$ & \\
\hline 2. & RMSEA & 0.013 & $\begin{array}{c}\leq 0.08 \\
0.08-0.10\end{array}$ & Good Fit \\
\hline 3. & $\mathrm{NFI}$ & 0.92 & $\begin{array}{c}\geq 0.90 \\
0.80-0.89\end{array}$ & Marginal Fit \\
\hline 4. & NNFI & 0.89 & $\begin{array}{c}\geq 0.90 \\
0.80-0.89\end{array}$ & Marginal Fit \\
\hline 5. & CFI & 0.92 & $\begin{array}{c}\geq 0.90 \\
0.80-0.89\end{array}$ & Good Fit \\
\hline 6. & IFI & 0.92 & $\begin{array}{c}\geq 0.90 \\
0.80-0.89\end{array}$ & Good Fit \\
\hline 7. & RMR & 0.025 & $\begin{array}{c}\leq 0.05 \\
0.05-0.10\end{array}$ & Good Fit \\
\hline 8. & GFI & 0.85 & $\begin{array}{c}\geq 0.90 \\
0.80-0.89\end{array}$ & Marginal Fit \\
\hline 9. & AGFI & 0.86 & $\begin{array}{c}\geq 0.90 \\
0.80-0.89\end{array}$ & Marginal Fit \\
\hline
\end{tabular}

Source: Data processing 
The subsequent analysis is Structural Equation Modeling (SEM) analysis in the full model. Analysis of data processing results at SEM full model stage performs by conducting model feasibility test and statistic test of the quality of service (QS) and tax sanction (TS) on service satisfaction (SS) and its implementation on personal vehicle tax compliance (TPC). The result refers to the fit model criteria contained in the following Goodness of Fit Index table. Table 5 shows that the model as a whole (Full Model) produced is a model that Fit so that it can continue in the next analysis. The predicted results for full model SEM analysis based on t-value shown in Figure 6.

\section{Figure 6. The Predicted Results of Full Model based on t-value}

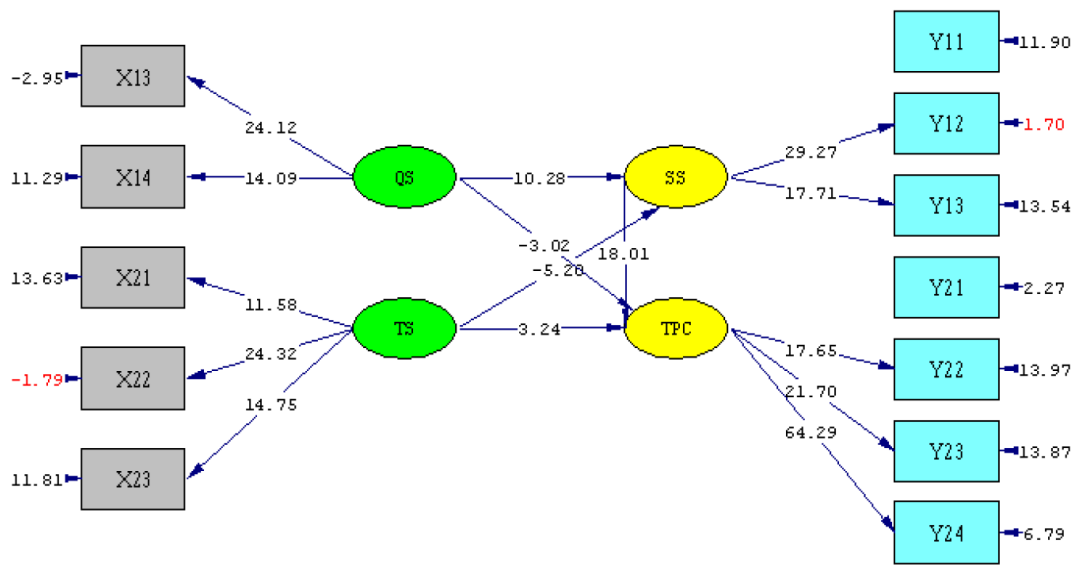

Chi-Square $=406.23, \mathrm{df}=48, \mathrm{P}$-value $=0.05142, \mathrm{RMSEA}=0.013$

Figure 6 show that all parameters in the Full Model significantly influence the value of the t-value. The predicted results for full model SEM analysis based on loading standards show in Figure 7.

Figure 7. The Predicted Results of Full Model

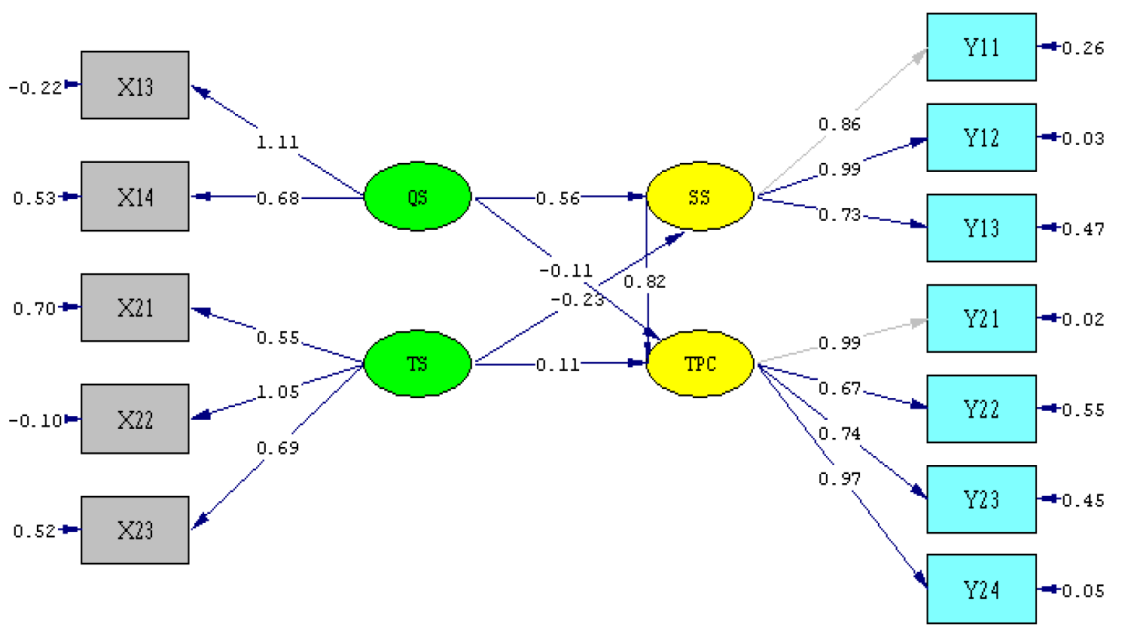

Chi-Square=406.23, df $=48$, P-value $=0.05142$, RMSEA $=0.013$

Based on the above loading standard results, the structural equation obtains as follows. 


\section{Sub-Structural Equation:}

$$
\mathrm{SS}=0.56^{*} \mathrm{QS}+(-0.23) * \mathrm{TS}
$$

Based on the structural model, it can explain that Quality of Service (QS) to the service satisfaction (SS) of 0.56 and Tax Sanctions (TS) to service satisfaction (SS) of -0.23 . This result means that the better service quality $(\mathrm{QS})$ then service satisfaction (SS) at UPTD Palembang Local Revenue Office of South Sumatra Province is getting better. While the Tax Sanctions (TS) showed a negative influence on service satisfaction (SS), the higher the value of Tax Sanctions will make Satisfaction of Services decreased. Rha (2012) concludes that the effect of the relationship and design qualities on customer satisfaction is stronger than the effect of service quality in public service.

\section{Structural Equation:}

\section{$\mathrm{TPC}=0.82 * \mathrm{SS}+(-0.11)^{*} \mathrm{Q} S+0.11^{*} \mathrm{TS}$}

Based on the structural model, it can explain that Personal Vehicle Tax Payable Compliance (TPC) is directly affected service satisfaction (SS), Quality of Service (QS), and Tax Sanctions (TS). This shows the effect of Satisfaction of Services (SS) on the Personal Vehicle Tax Payable Compliance (TPC) of 0.56, the influence of Quality of Service (QS) on the Personal Vehicle Tax Payable Compliance (TPC) of (-0.11) and the effect of Tax Sanctions (TS) against Personal Vehicle Tax Payable Compliance (TPC) of 0.11. Variable Satisfaction Of Services (SS) has the most dominant effect on Personal Vehicle Tax Payable Compliance (TPC) at UPTD Palembang Local Revenue Office of South Sumatera Province.

Direct influence analysis is intended to see how strong the influence of a variable with other variables directly and the interpretation of these results will have significant meaning to determine a clear strategy in order to improve the Employee Performance Inspectorate of South Sumatra Province. The calculation results of direct influence are showing in Table 6.

Table 6. Direct Influence

\begin{tabular}{clcc}
\hline & QS & TS & SS \\
\hline SS & 0.56 & -0.23 & \\
TPC & -0.11 & 0.11 & 0.82 \\
\hline \multicolumn{4}{l}{ Source: Data processing }
\end{tabular}

Based on the results of Table 6, the number of Direct Influence of Quality of Service (QS) to Service Satisfaction (SS) of 0.60, Tax Sanction (TS) to Service Satisfaction (SS) of -0.23 , Quality of Service (QS) on tax pay compliance (TPC) of -0.11, Tax Sanction (TS) on tax pay compliance (TPC) of -0.11 , Service Satisfaction (SS) on tax compliance (TPC) of 0.82 . The most dominant direct influence on Personal Vehicle Tax Payable Compliance (TPC) is the service satisfaction variable (SS) of 0.82 . Thus, service satisfaction felt by taxpayers will affect the tax pay compliance. Taxpayers will comply with the payment of vehicle tax is not always due to the threat of sanctions, but compliance can arise due to perceived service satisfaction, especially 
given by the UPTD Palembang Regional Revenue Service of South Sumatra Province. Physical facilities of equipment and appearance of UPTD Palembang employees Regional Revenue Service of South Sumatra Province is declared to be quite good dominate by respondents.

The ability of employees to provide services, accuracy, and consistency is stated by the dominant respondents to be good. Likewise, the ability to provide fast services and help taxpayers are declared to be reasonably good dominate by the taxpayer respondents. Whereas the employee's knowledge, manners, and abilities convey certainty and trust are declared dominant both by the respondent. The individual attention of employees to taxpayers is declared to be quite good dominate by the respondents. Service quality must be improved again in order to increase taxpayer satisfaction and compliance (Viani \& Budi, 2012). As an effort to improve the quality and technical capabilities of employees in the field of taxation, the use of information systems and technology to provide convenience to taxpayers in fulfilling their tax obligations. According to Marjan (2014), the issue of the low level of taxpayer compliance is critical because non-compliance with taxation will result in efforts to avoid and tax evasion. This condition will indirectly lead to reduce tax revenues to the Indonesian state treasury. According to Susmita \& Upadmi (2016), compliance with taxpayers is a behavior of a taxpayer in carrying out all tax obligations and uses his taxation rights while still adhering to the applicable tax laws and regulations.

The analysis of indirect influence is intended to see how strongly the influence of a variable with other variables is indirectly, and the interpretation of these results will have important meanings for defining a clear strategy in order to increase taxpayer compliance of personal vehicles. The calculation results of indirect influence are showing in Table 7.

Table 7. Indirect Influence

\begin{tabular}{ccc}
\hline & QS & TS \\
\hline SS & & \\
TPC & 1.38 & 0.59 \\
\hline
\end{tabular}

The analysis of indirect influence is intended to see how strongly the influence of a variable with other variables is indirectly, and the interpretation of these results will have important meanings for defining a clear strategy in order to increase taxpayer compliance of personal vehicles. The calculation results of indirect influences are as follows. Thus, the quality of service felt by taxpayers for services provided by the UPTD Palembang South Sumatra Provincial Revenue Service influences tax pay compliance. This study supports previous research conducted by Susmita \& Upadmi (2016) that found a significant effect of service quality on the compliance of taxpayers. Jotopurnomo\& Mangoting (2013) obtained results where taxation sanctions for taxpayer compliance increased due to taxpayers who had understood taxation law would choose to be obedient compared to being subject to taxation sanctions, which caused more harm. 


\section{Conclusion}

The conclusions obtained from this study: first, the service quality affects service satisfaction, and it implies on tax compliance. The excellent quality of service provided by the Palembang UPTD Regional Revenue Service of the Province of South Sumatra will affect the tax revenue received. Because the quality of service will base on taxpayers so that taxpayers in fulfilling obligations in paying taxes to avoid tax sanctions and also the income received by UPTD Palembang increases. Second, tax sanctions affect service satisfaction and its implications for compliance with paying personal vehicle tax at the Palembang UPTD Regional Revenue Service of South Sumatra Province. Tax sanctions are a prevention tool for violations committed by taxpayers. If Service Satisfaction fails to meet expectations, taxpayers will dissatisfy. If Service Satisfaction is in line with expectations, taxpayers will be satisfied. If Service Satisfaction exceeds expectations, taxpayers will be very satisfied or happy.

\section{References}

Andreassen, T. W. (1994). Satisfaction, Loyalty, and Reputation as Indicators of Customer Orientation in the Public Sector. International Journal of Public Sector Management, 7(2), 16-34. https://doi.org/10.1108/09513559410055206.

Andreassen, T. W. (1995). (Dis)satisfaction with Public Service: the Case of Public Transportation. Journal of Services Marketing, 9(5), 30-41. https://doi.org/10.1108/ 08876049510100290.

Asbar, A. K., Fitros, R., \& Rusli. (2014). Pengaruh Tingkat Kepuasan Pelayanan, Pemahaman Perpajakan, Keadilan Perpajakan, Sanksi Perpajakan dan Kesadaran Perpajakan terhadap Tingkat Kepatuhan Wajib Pajak Orang Pribadi pada KPP Pratama Senapelan Pekanbaru (Effect of Service Satisfaction Levels, Taxation Understanding, Tax Justice, Tax Sanctions and Tax Awareness on the Level of Compliance of Individual Taxpayers at KPP Senapelan Pekanbaru). JOM FEKOM, 1(2), 1-15.

Chau, G., \& Leung, P. (2009). A Critical Review of Fischer Tax Compliance Model : a Research Synthesis. Journal of Accounting and Taxation, 1(2), 34-40. https://doi. org/10.5897/JAT09.021

Devano, S., \& Rahayu. (2016). Perpajakan: Konsep, Teori dan Isu (Taxation: Concepts, Theories and Issues.). Jakarta: Kencana.

Hardiningsih, P., \& Yulianawati, N. (2011). Faktor-Faktor Yang Mempengaruhi Kemauan Membayar Pajak (The Factors That Affect the Will to Pay Taxes.). Dinamika Keuangan dan Perbankan, 3(1), 126-142. https://doi.org/ISSN: 1979-4878

Jotopurnomo, C., \& Mangoting, Y. (2013). Pengaruh Kesadaran Wajib Pajak, Kualitas Pelayanan Fiskus, Sanksi Perpajakan, Lingkungan Wajib Pajak Berada terhadap Kepatuhan Wajib Pajak Orang Pribadi di Surabaya (The Influence of Taxpayer Awareness, Fiscus Service Quality, Tax Sanctions, Environmental Taxpayers Being on the Compliance of Individual Taxpayers in Surabaya). Jurnal Tax \& Accounting Review, 1(1), 49-54.

Mardiasmo. (2009). Perpajakan (Taxation). Yogyakarta: Penerbit Andi Offset. 
Marjan, R. M. (2014). Pengaruh Kesadaran Wajib Pajak, Pelayanan Fiskus, dan sanksi Pajak Terhadap Tingkat Kepatuhan Formal Wajib Pajak: Studi di KPP Pratama Makasar Selatan (The Effects of Taxpayer Awareness, Fiscus Services, and Tax sanctions on the Formal Taxpayer Compliance Level: Study at KPP Pratama Selatan Makassar). Unpublished Bachelor Thesis. Makasar: Universitas Hasanuddin.

Putri, K. J., \& Setiawan, P. E. (2017). Pengaruh Kesadaran, Pengetahuan dan Pemahaman perpajakan, Kualitas Pelayanan, dan Sanksi Perpajakan Terhadap Kepatuhan Wajib Pajak (The Effect of Tax Awareness, Knowledge and Understanding, Service Quality, and Tax Sanctions on Taxpayer Compliance). E-Jurnal Akuntansi Universitas Udayana, 18(2), 1112-1140.

Ramseook-Munhurrun, P., Lukea-Bhiwajee, S. D., \& Naidoo, P. (2010). Service Quality in the Public Service. International Journal of Management and Marketing Research, 3(1), 37-50.

Rha, J. Y. (2012). Customer Satisfaction and Qualities in Public Service: an Intermediary Customer Perspective. The Services Industries Journal, 32(12), 1883-1900. https://doi. org/10.1080/02642069.2011.574274.

Septarini, D. F. (2015). Pengaruh Pelayanan, Sanksi, Dan Kesadaran Wajib Pajak Terhadap Kepatuhan Wajib Pajak Orang Pribadi Di KPP Pratama Merauke (The Effect of Services, Sanctions, and Awareness of Taxpayers on the Compliance of Individual Taxpayers in Merauke KPP). Jurnal Ilmu Ekonomi \& Sosial, VI(1), 29-43.

Susmita, P. R., \& Upadmi, N. L. S. (2016). Pengaruh Kualitas Pelayanan, Sanksi E-Filing pada Kepatuhan Wajib Pajak (Effect of Service Quality, E-Filing Sanctions on Taxpayer Compliance). E-Jurnal Akuntansi, 14(2), 1239-1269.

Suwardi., \& Utomo, J. (2011). Pengaruh Motivasi Kerja, Kepuasan kerja, dan Komitmen Organisasi Terhadap Prestasi Kerja Pegawai (The Effect of Work Motivation, Job Satisfaction, and Organizational Commitment on Employee Job Performance). Jurnal Analisis Manajemen, 5(1), 75-86.

Syahril, F. (2013). Pengaruh Tingkat Pemahaman Wajib Pajak dan Kualitas Pelayanan Fiskus Terhadap Tingkat Kepatuhan Wajib Pajak Pph Orang Pribadi (The Effect of Taxpayer Understanding Level and Fiscus Service Quality on the Level of Compliance of Personal Taxpayers). Unpublished Thesis. Padang: Universitas Negeri Padang.

Viani, Y. R. N., \& Budi, Y. A. B. (2012). Pengaruh Kualitas Pelayanan Terhadap Kepatuhan Membayar Wajib Pajak: Studi Kasus di KPP Jakarta Kelapa Gading (Effect of Service Quality on Compliance Paying Taxpayers: Case Study at KPP Jakarta Kelapa Gading). Jurnal Informasi, Perpajakan, Akuntansi Dan Keuangan Publik, 7(1), 61-72. 